\title{
KINERJA CAMPURAN SMA DENGAN MENGGUNAKAN PASIR PANTAI INDRAYANTI SEBAGAI PENGGANTI AGREGAT HALUS
}

\author{
Farkhan Ramadhan ${ }^{1, *}$, Miftahul Fauziah ${ }^{2}$ \\ ${ }^{1, *}$ Program Studi Teknik Sipil, Universitas Islam Indonesia \\ Email: 15511191@uii.ac.id \\ ${ }^{2}$ Program Studi Teknik Sipil, Universitas Islam Indonesia \\ Email: miftahul.fauziah@uii.ac.id
}

\begin{abstract}
Split Mastic Asphalt (SMA) mixture is one of the favored materials for flexible pavement in Indonesia. Due to the limitation of fine aggregate products from stone crusher, therefore, an alternative sand beach is used. This paper presents the results of determining the influence of the use of coastal sand as fine aggregate substitution on the Split mastic asphalt (SMA). This research has four phases, first testing of aggregate and asphalt properties, then the determination of optimum asphalt content $0 \%, 25 \%, 50 \%, 75 \%$, and 100\%. The next step was testing Marshall, Immersion, Indirect Tensile Strength, and Cantabro loss. The results showed that the use of Indrayanti's sand beach as a substituted fine aggregate on the Split Mastic Asphalt 0/11 mixture meets the standard. Based on Marshall's test stability and flexibility of all the mixture was higher, the Bina Marga specification. Indirect Tensile Strength increase in each addition of Indrayanti's sand beach. Cantabro Loss and Index Retained Strength on all specimens of Indrayanti's sand beach qualify Bina Marga standard.
\end{abstract}

Keywords: Split mastic asphalt, fine aggregate, Indrayanti beach sand

\section{PENDAHULUAN}

Pada umumnya infrastruktur jalan di Indonesia menggunakan flexible pavement dengan menggunakan campuran aspal panas. Salah satunya adalah Split Mastic Asphalt (SMA), campuran SMA terdiri dari agregat kasar, agregat halus, dan filler. Menurut Lake dkk (2010) Split Mastic Asphalat ini merupakan campuran beton aspal dengan kandungan agregat kasar \pm $70 \%$ dan filler $\pm 11 \%$. Campuran SMA lebih tahan terhadap deformasi mempunyai skid resistence tinggi karena kadar agregat kasarnya besar dan mempunyai kecenderungan lebih tahan lama, karena kadar aspalnya tinggi dan distabilisasi dengan serat selulosa, sehingga dapat melayani beban kendaraan lebih baik. Di Daerah Istimewa Yogyakarta (DIY) umumnya menggunakan agregat halus yang berasal dari Clereng, Kulonprogo yang setiap tahun kebutuhannya selalu bertambah sehingga dibutuhkan inovasi. Salah satu alternatif yang bisa digunakan adalah pasir pantai.

Penggunaan pasir pantai sebagai agregat halus telah dikaji oleh banyak peneliti sebelumnya. Kusharto (2004) meneliti pengaruh penggunaan pasir pantai terhadap sifat Marshall dalam campuran beton aspal. Hasil penelitian merekomendasikan perlu dikaji dan diteliti secara mendalam sifat kimia batuan terutama pada mekanisme lekatan batuan pasir pantai terhadap aspal, pengaruh kadar garam terhadap sifat aspal dan perlu diteliti lebih lanjut mengenai sifatsifat, karakteristik beton aspal yang lain yaitu nilai structural, skid resistence, fleksibilitas, impermeabilitas campuran. Pengaruh waktu terhadap daya tahan lapis perkerasan yang menggunakan bahan susun pasir pantai yang dikaji oleh Proyowardono (2004) didapatkan kesimpulan pasir pantai 
dapat digunakan sebagai bahan susun lapis perkerasan dan mempunyai kekuatan cukup baik tetapi dari segi keawetan kurang baik untuk digunakan sebagai lapis perkerasan. Penelitian yang dilakukan Zakaria dan Fauziah (2012) tentang penggunaan pasir Bengawan Solo sebagai agregat halus pada campuran $A C-B C$ menghasilkan bahwa penggunaan pasir Bengawan Solo dapat digunakan sebagai agregat halus kerena memenuhi persyaratan Bina Marga dan proporisi optimum penggunaan pasir Bengawan Solo sebagai agregat halus pengganti pada campuran AC-BC sebesar proporsi $25 \%$ terhadap total agregat halus yang dibutuhkan. Studi yang dilakukan oleh Fauziah (2013) mengenai penggunaan pasir sungai Bengawan Solo terhadap nilai stabilitas, nilai tensile strength, dan nilai kekakuan menyimpulkan bahwa nilai stabilitas, indirect tensile, dan kekakuan penggunaan pasir Bengawan Solo bernilai lebih rendah daripada penggunaan agregat yang diproduksi oleh stone crusher. Bestari (2013) meneliti penggunaan pasir pantai Bakau sebagai campuran aspal beton jenis $H R S$ dan menyimpulkan bahwa secara umum pasir pantai Bakau memenuhi persyaratan Marshall. Penelitian penggunaan pasir pantai Carita sebagai campuran agregat halus pada lapis permukaan aspal beton terhadap persyaratan parameter Marshall yang dilakukan oleh Arifiardi (2016) menyimpulkan bahwa penggunaan pasir pantai Carita sebesar 50\% memenuhi persyaratan yang sudah ditetapkan akan tetapi penggunaan $100 \%$ agregat halus pasir pantai hanya memenuhi persyaratan flow, $V M A, V I T M$, VFWA. Nilai stabilitas dan $M Q$ tidak memenuhi syarat sehingga penggunaan $100 \%$ agregat halus pasir pantai tidak dapat dijadikan bahan subtitusi secara keseluruhan sebagai agregat halus pada bahan perkersasan $A C-W C$. Pataras dkk (2017) meninjau penggunaan pasir pantai, darat, dan sungai terhadap kinerja laston dan lataston wearing course mendapatkan kesimpulan bahwa campuran pasir pantai
Bengkulu memiliki nilai $V M A$ terkecil yang mengindikasikan rongga yang berada pada campuran pasir pantai mampu menyerap dengan baik dan campuran pasir sungai merupakan campuran perkerasan yang memiliki kualitas terbaik dibandingkan dengan pasir darat dan pasir pantai. Penelitian yang belum lama ini dilakukan oleh Shabrina (2019) tentang pemanfaatan pasir pantai Kemala sebagai bahan tambah campuran $A C-W C$ terhadap Marshall properties dan nilai struktural menyimpulkan bahwa variasi subtitusi pada pada variasi $30 \%$ tidak memenuhi persyaratan $800 \mathrm{~kg}$. Sedangkan nilai flow berturut-turut mengalami penurunan yang disebabkan oleh campuran yang semakin kaku seiring penambahan pasir pantai, nilai $V M A$ dan VIM rata-rata menurun dan nilai $V F W A$ mengalami mengalami kenaikan disebabkan penambahan pasir pantai pada campuran sehingga rongga yang terisi aspal bertambah meskipun kadar aspal tetap, nilai $M Q$ berturut turut meningkat. Proporsi pasir pantai ditinjau dari koefisien kekuatan relatif bahan (a) yang optimal terdapat pada variasi $15 \%$.

Sunarjono dan Samantha (2012) melakukan investigasi tentang analisis kekuatan tarik material campuran SMA (Split Mastic Asphalt) Grading 0/11 menggunakan sistem pengujian Indirect Tensile Strength (ITS). Pengujian ITS terhadap pembebanan tarik $S M A$ dalam berbagai variasi kadar aspal, nilai ITS cenderung meningkat dan mengalami penurunan setelah kadar aspal sudah melampaui nilai optimum yang dibutuhkan.

Penelitian tentang analisis workabilitas dan durabilitas material spli Mastic Asphalt (SMA) grading 0/11 pada gradasi batas atas, batas bawah, dan batas tengah dilakukan oleh Ramdhan (2018) menyimpulkan berdasarkan nilai durabilitas gradasi tengah memiliki nilai terbaik dikarenakan mimiliki nilai IKS atau IRS tertinggi namun pada perhitungan nilai Indeks Durabilitas Pertama 
(IDP) dan Indeks Durabilitas Kedua (IDK) memimiliki nilai kehilangan kekuatan terbesar.

Makalah ini menyajikan hasil pengukuran untuk Kinerja campuran SMA dengan menggunakan pasir pantai Indrayanti sebagai pengganti agregat halus dengan bahan ikat pen 60/70 ditinjau dengan pengujian Marshall Standard, Index of Retained Strength (IRS), Indriect Tensile Strength (ITS), Cantabro Loss (CL).

\section{METODE PENELITIAN}

Pengujian pada penelitian ini dilaksanakan di Laboratorium Jalan Raya Jurusan Teknik Sipil dan Perencanaan, Universitas Islam Indonesia. Agregat yang digunakan adalah agregat yang berasal dari Clereng, Kulonprogo dan pasir pantai menggunakan pasir pantai Indrayanti Gunung kidul tanpa dilakukan pencucian terlebih dahlulu. Bahan ikat yang digunakan adalah aspal pertamina pen 60/70. Serat selulosa yang digunakan merupakan serat selulosa alami berupa dedak padi. Tahapan awal penelitian adalah melakukan pengujian terhadap sifat fisik material yang berdasarkan Bina Marga 2010, yaitu pengujian karakteristik agregat aspal pen $60 / 70$. Tahap selanjutnya adalah membuat benda uji dengan gradasi campuran Split Mastic Asphalt (SMA) 0/11 berdasarkan Departemen Perkembangan wilayah (1999) kemudian membuat benda uji dengan variasi subtitusi agregat halus pasir pantai Indrayanti dengan variasi $0 \%$, $25 \%, 50 \%, 75 \%$, dan $100 \%$ pasir pantai Indrayanti. Selanjutnya dilakukan pengujian benda uji dengan parameter Marshall Standard, IRS, ITS, Cantabro.

\section{HASIL DAN PEMBAHASAN}

\section{Pengujian Sifat Fisik Bahan}

Hasil pengujian sifat fisik bahan yang digunakan dapat dilihat pada Tabel 1 sampai dengan Tabel 5.

Tabel 1. Hasil uji aspal pen 60/70

\begin{tabular}{|c|l|c|c|}
\hline No & \multicolumn{1}{|c|}{ Jenis Pengujian } & Syarat & Hasil \\
\hline 1 & Berat Jenis & $\geq 1,0$ & 1,023 \\
\hline 2 & Penetrasi $(\mathrm{mm})$ & $60 / 70$ & 62,3 \\
\hline 3 & Daktilitas $(\mathrm{cm} 1)$ & $\geq 100$ & 164 \\
\hline 4 & Titik Lembek $\left({ }^{\circ} \mathrm{C}\right)$ & $\geq 48$ & 48 \\
\hline 5 & Titik Nyala $\left({ }^{\circ} \mathrm{C}\right)$ & $\geq 232$ & 332 \\
\hline 6 & Titik Bakar $\left({ }^{\circ} \mathrm{C}\right)$ & $\geq 232$ & 345 \\
\hline 7 & Kelarutan pada TCE $(\%)$ & $\geq 99$ & 99,03 \\
\hline
\end{tabular}

Tabel 2. Hasil uji agregat kasar

\begin{tabular}{|c|l|c|c|}
\hline No & \multicolumn{1}{|c|}{ Jenis Pengujian } & Syarat & Hasil \\
\hline 1 & Berat Jenis & $\geq 2,5$ & 2,6643 \\
\hline 2 & $\begin{array}{l}\text { Penyerapan Agregat } \\
\text { Terhadap Air (\%) }\end{array}$ & $\leq 3$ & 1,687 \\
\hline 3 & $\begin{array}{l}\text { Kelekatan Agregat } \\
\text { Terhadap Aspal (\%) }\end{array}$ & $\geq 95$ & 97,5 \\
\hline 4 & $\begin{array}{l}\text { Keausan Agregat dengan } \\
\text { Mesin Los Angeles (\%) }\end{array}$ & $\geq 40$ & 13,07 \\
\hline
\end{tabular}

Tabel 3. Hasil uji agregat halus

\begin{tabular}{|c|l|c|c|}
\hline No & \multicolumn{1}{|c|}{ Jenis Pengujian } & Syarat & Hasil \\
\hline 1 & Berat Jenis & $\geq 2,5$ & 2,60 \\
\hline 2 & $\begin{array}{l}\text { Penyerapan Agregat } \\
\text { Terhadap Air (\%) }\end{array}$ & $\leq 3$ & 2,25 \\
\hline 3 & Sand Equivalent (\%) & $\geq 50$ & 91,98 \\
\hline
\end{tabular}

Tabel 4. Hasil uji agregat halus pasir pantai

\begin{tabular}{|c|l|c|c|}
\hline No & \multicolumn{1}{|c|}{ Jenis Pengujian } & Syarat & Hasil \\
\hline 1 & Berat Jenis & $\geq 2,5$ & 2,85 \\
\hline 2 & $\begin{array}{l}\text { Penyerapan Agregat } \\
\text { Terhadap Air (\%) }\end{array}$ & $\leq 3$ & 0,99 \\
\hline 3 & Sand Equivalent (\%) & $\geq 50$ & 81 \\
\hline
\end{tabular}

Tabel 5. Hasil uji filler abu batu

\begin{tabular}{|c|c|c|c|}
\hline No & Filler & Syarat & Hasil \\
\hline 1 & Berat Jenis & $\leq 8$ & 2,553 \\
\hline
\end{tabular}




\section{Karakteristik Marshall}

Karakteristik Marshall yang ditinjau pada berbagai kadar aspal adalah berupa stabilitas, flow, Marshall Quetient (MQ), (VITM) Void In Total Mix, (VFWA) Void Filled With Asphalat, (VMA) Void Mineral Aggregat, density, pengujian ini digunakan untuk mendapatkan nilai masing masing KAO pada masing-masing Kadar subtitusi pasir pantai Indrayanti. Berikut adalah rekapitulasi nilai Kadar Aspal Optimum (KAO) pada Tabel 6.

Tabel 6. Rekapitulasi KAO

\begin{tabular}{|c|c|c|c|}
\hline $\begin{array}{c}\text { Variasi } \\
\text { Subtitusi } \\
\text { Pasir Pantai } \\
\text { Indrayanti } \\
(\%)\end{array}$ & $\begin{array}{c}\text { Kadar } \\
\text { Aspal } \\
\text { Minimum } \\
(\%)\end{array}$ & $\begin{array}{c}\text { Kadar Aspal } \\
\text { Maksi-mum } \\
(\%)\end{array}$ & $\begin{array}{c}\text { Kadar } \\
\text { Aspal } \\
\text { Optimum } \\
(\%)\end{array}$ \\
\hline 0 & 6,89 & 7,5 & 7,19 \\
\hline 25 & 7,12 & 7,5 & 7,31 \\
\hline 50 & 7,32 & 7,5 & 7,41 \\
\hline 75 & 7,40 & 7,5 & 7,45 \\
\hline 100 & 7,45 & 7,5 & 7,47 \\
\hline
\end{tabular}

Berdasarkan Tabel 6 dapat disimpulkan bahwa setiap penambahan variasi subtitusi pasir pantai Indrayanti maka, semakin besar kadar aspal yang dibutuhkan.

\section{Nilai Marshall pada KAO}

Hasil pengujian kinerja campuran SMA 0/11 menggunakan pasir pantai Indrayanti menunjukan penururan kinerja stabilitas dapat dilihat pada Gambar 1.

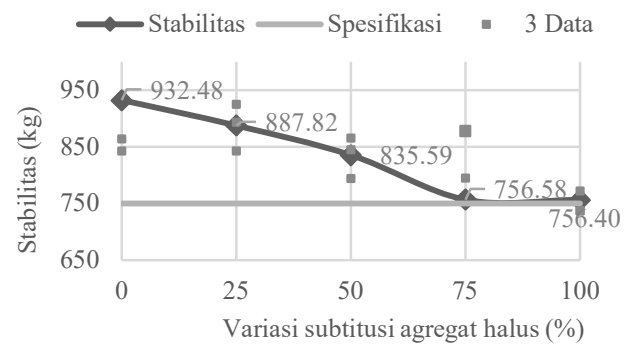

Gambar 1. Grafik pengaruh variasi subtitusi pasir pantai terhadap nilai stabilitas

Penambahan variasi subtitusi pasir pantai mengakibatkan penunurunan nilai stabilitas yang disebabkan oleh kondisi agregat pasir pantai yang permukaannya lebih halus, dan bentuknya yang lebih bulat. Kondisi ini menyebabkan ikatan antara pasir pantai dan aspal lebih rendah dibandingkan dengan agregat halus Clereng yang memiliki tekstur permukaan kasar yang menyebabkan nilai stabilitas semakin menurun setiap kali ada penambahan variasi subtitusi pasir pantai. Hal ini sejalan dengan penelitian yang dilakukan oleh Arifiardi, dkk (2016) yang menggunakan pasir pantai Carita, Priyowardono (2004) yang menggunakan pasir pantai Parangtritis sebagai agregat halus, Zakaria dan Fauziah (2012) dan Fauziah (2013) yang menggunakan pasir sungai Bengawan Solo dan Bestari (2013) yang menggunakan pasir pantai Bakau.

Nilai flow pada kinerja campuran SMA 0/11 menggunakan pasir pantai Indrayanti dapat dilihat pada Gambar 2.

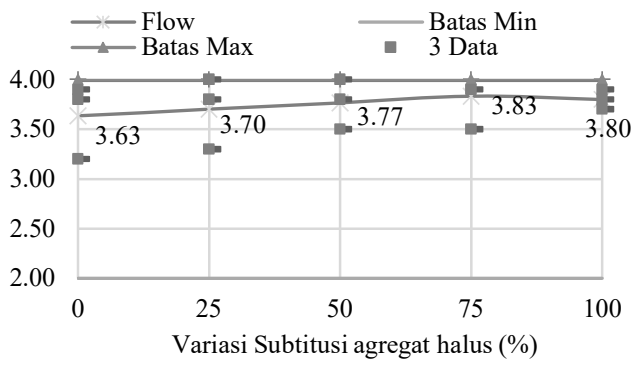

Gambar 2. Grafik pengaruh variasi subtitusi pasir pantai terhadap nilai flow

Pada umumnya nilai flow mengalami kenaikan setiap penambahan variasi subtitusi pasir pantai, kadar aspal yang digunakan juga semakin tinggi, penggunaan kadar aspal yang tinggi disebabkan permukaan agregat pasir pantai yang cenderung lebih halus daripada agregat halus Clereng, sehingga dibutuhkan kadar aspal yang lebih banyak untuk menyelimuti campuran. Namun dengan penggunaan kadar aspal yang tinggi dapat mengakibatkan mudah terjadinya bleeding. Campuran dengan kadar aspal yang tinggi mengakibatkan campuran lebih plastis dan cenderung mudah mengalami deformasi. Hal ini sejalan dengan penelitian Pataras, dkk (2017) yang menggunakan pasir 
pantaidan Kusharto (2004), Peningkatan nilai flow menunjukkan jika campuran $S M A$ $0 / 11$ lentur dan plastis.

Nilai marshall quotient pada kinerja campuran SMA 0/11 menggunakan pasir pantai Indrayanti dapat dilihat pada Gambar 3 berikut ini.

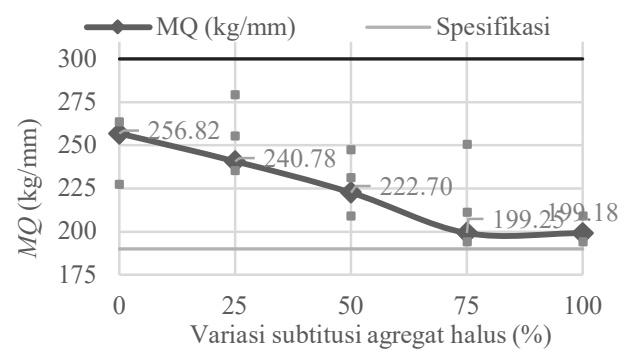

Gambar 3. Grafik pengaruh variasi subtitusi pasir pantai terhadap nilai $M Q$

Nilai $M Q$ pada setiap penambahan variasi subtitusi pasir pantai sebagai agregat halus mengalami penurunan namun tetap masuk dalam spesifikasi yang disyaratkan. Hal ini sejalan dengan penelitian Arifiardi (2016) dengan penambahan variasi pasir pantai pada campuran $A C-W C$ nilai $M Q$ pada subtitusi $0 \%$ dan 50\% masih masuk spesifikasi, sedangkan pada subtitusi $100 \%$ tidak masuk dalam spesifikasi yang disyaratkan Bina Marga.

Kinerja nilai VITM (Void in Total Mix) pada kinerja campuran SMA 0/11 menggunakan pasir pantai Indrayanti dapat dilihat pada Gambar 4.

Setiap penambahan variasi subtitusi pasir pantai sebagai agregat halus mengalami kenaikan yang menunjukan bahwa rongga dalam campuran semakin besar setiap penambahan variasi subtitusi pasir pantai. Beberapa penyebab campuran mudah dilalui oleh air, antara lain: aspal kurang menyelimuti pasir pantai dan juga pasir pantai tidak mengisi rongga-rongga yang ada dalam campuran akibat bentuk pasir pantai yang cenderung bulat, dengan nilai VITM yang besar, dan nilai porositas yang terdapat dalam campuran juga besar. Hal ini sejalan dengan penelitian Arifriardi, dkk (2016) dan kajian yang dilakukan oleh Zakaria dan Fauziah (2012).

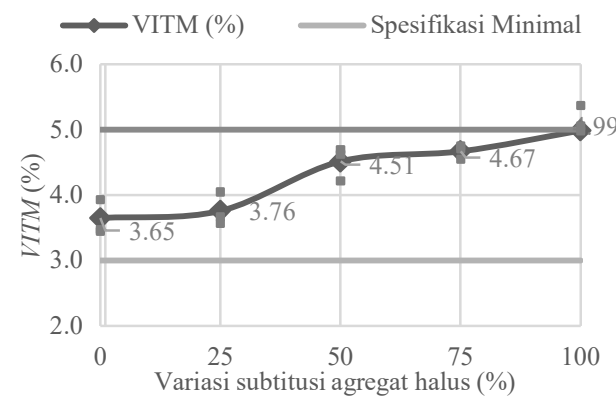

Gambar 4. Grafik pengaruh variasi subtitusi pasir pantai terhadap nilai VITM

Kinerja nilai VFWA (Void Filled With Asphalt) pada kinerja campuran SMA 0/11 menggunakan pasir pantai Indrayanti dapat dilihat pada Gambar 5.

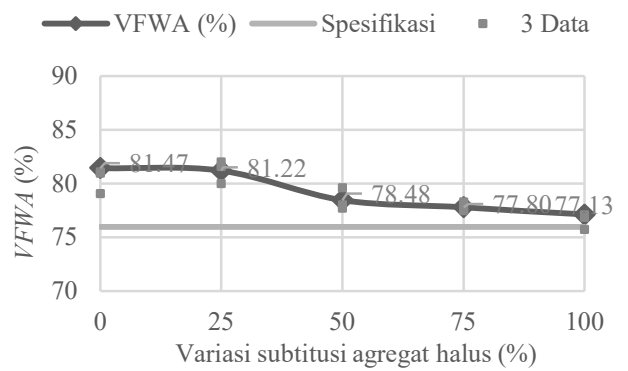

Gambar 5. Grafik pengaruh variasi subtitusi pasir pantai terhadap nilai $V F W A$

Nilai $V F W A$ pada setiap penambahan variasi subtitusi pasir pantai sebagai agregat halus mengalami penurunan setiap penambahan variasi subtiusi pasir pantai Indrayanti, dikarenakaan aspal yang menyelimuti agregat semakin tipis dalam penambahan variasi subtitusi pasir pantai kandungan garam yang terdapat pada pasir pantai Indrayanti dalam campuran menyerap air. Nilai VFWA yang rendah akan menyebabkan kekedapannya terhadap air semakin berkurang dan dapat mengakibatkan daya tahan pada campuran berkurang. Hal ini sejalan dengan kajian yang dilakukan Priyowardano (2004), yang menggunakan 
pasir pantai Parangtritis dan penelitian Arifriadi (2016) yang menggunakan pasir pantai Carita.

Nilai VMA (Void Mineral in Aggregate) pada kinerja campuran SMA 0/11 menggunakan pasir pantai Indrayanti dapat dilihat pada Gambar 6 .

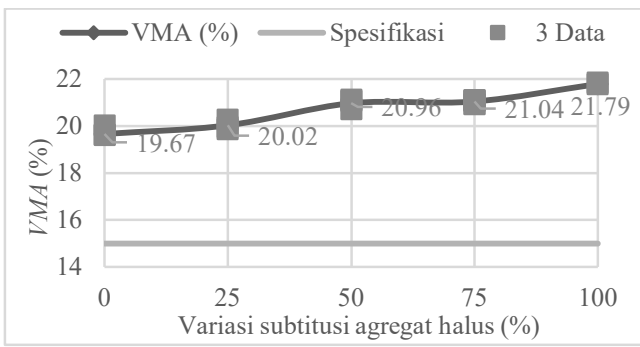

Gambar 6. Grafik pengaruh variasi subtitusi pasir pantai terhadap nilai $V M A$

Nilai $V M A$ pada setiap penambahan variasi subtitusi pasir pantai Indrayanti sebagai agregat halus mengalami kenaikan, dikarenakan pasir pantai tidak mengisi rongga rongga yang ada, sehingga mengakibatkan kemampuan interlocking pada campuran berkurang. Hal ini sesuai dengan penelitian Arifriardi (2016) dan Pataras, dkk (2017) bahwa nilai VMA pada variasi subtitusi agregat $0 \%, 50 \%$, dan $100 \%$ mengalami kenaikan namun tetap masuk dalam spesifikasi yang sudah ditentukan.

Nilai density pada kinerja campuran SMA 0/11 menggunakan pasir pantai Indrayanti dapat dilihat pada Gambar 7.

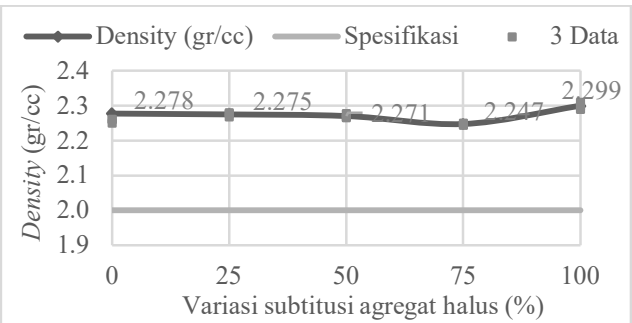

Gambar 7. Grafik pengaruh variasi subtitusi pasir pantai terhadap nilai density

Nilai density pada setiap penambahan variasi subtitusi pasir pantai sebagai agregat halus mengalami kenaikan, yang artinya semakin padatnya campuran, penelitian ini sejalan dengan penelitian Kusharto (2004) bahwa nilai density mengalami kenaikan namun tetap masuk dalam spesifikasi yang sudah ditentukan.

\section{KINERJA CAMPURAN PADA KAO}

\section{Indirect Tensile Strength}

Grafik hasil pengujian Indrirect Tensil Strength pada kinerja campuran SMA 0/11 menggunakan pasir pantai Indrayanti dapat dilihat pada Gambar 8 .

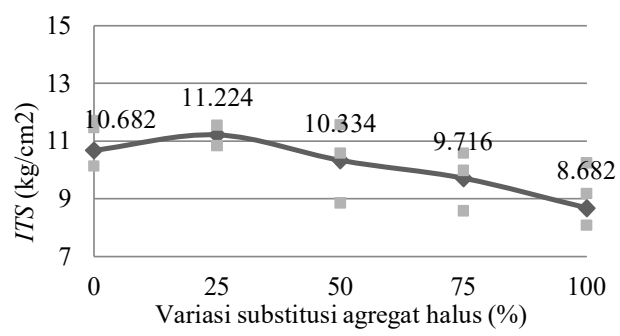

Gambar 8. Grafik pengaruh variasi subtitusi pasir pantai terhadap nilai ITS

Nilai pengujian kurat tarik tak langsung pada uji ITS pada setiap penambahan variasi subtitusi pasir pantai Indrayanti sebagai agregat halus mengalami penurunan, hal ini dikarenakan aspal menyelimuti agregat tipis, sehingga mempengaruhi campuran yang menyebabkan campuran menjadi mudah retak. Tekstur permukaan pasir pantai yang halus menyebabkan campuran mudah lepas akibat tarik dikarenakan ikatan antar agregat dan aspal menurun. Hal ini sejalan dengan penelitian Sunarjono dan Samantha (2012) yang melakukan analisis menggunakan campuran SMA 0/11 dengan hasil nilai ITS yang terus meningkat kemudian nilai ITS menurun.

\section{Cantabro Loss}

Nilai Cantabro loss pada kinerja campuran SMA 0/11 menggunakan pasir pantai Indrayanti dapat dilihat pada Gambar 9 berikut ini. 


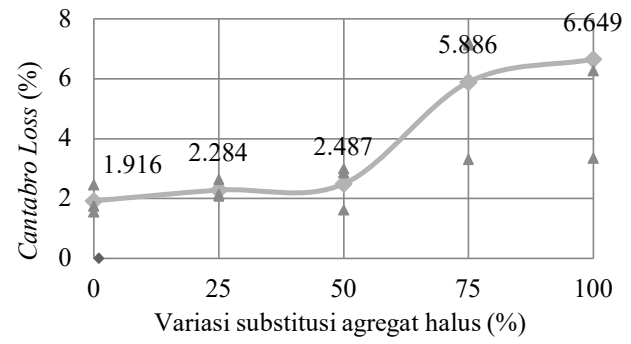

Gambar 9. Grafik pengaruh variasi subtitusi pasir pantai terhadap nilai Cantabro Loss

Nilai pengujian Cantabro loss pada setiap penambahan variasi subtitusi pasir pantai Indrayanti sebagai agregat halus mengalami kenaikan, yang artinya setiap penambahan kadar variasi pasir pantai Indrayanti ketahanan terhadap disintegrasi menjadi kurang baik yang menyebabkan kehilangan berat yang meningkat. Tekstur permukaan pasir pantai yang lebih halus menyebabkan campuran mudah lepas karena benturan dikarenakan ikatan antar agregat dan aspal menurun.

\section{Index of Retained Strength (IRS) dan Durabilitas}

Nilai grafik retained strength kinerja campuran SMA 0/11 menggunakan pasir pantai Indrayanti dapat dilihat pada Gambar 10.

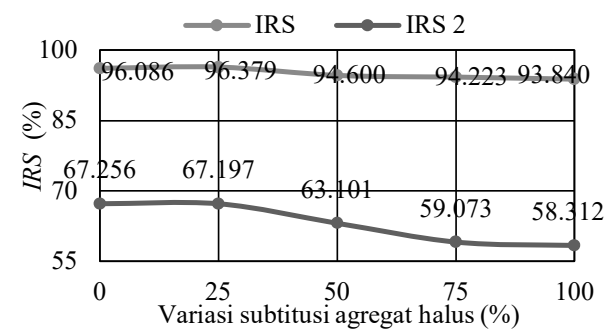

Gambar 10. Grafik pengaruh variasi subtitusi pasir pantai terhadap nilai Index

\section{Retained Strength}

Hasil uji retainded strength pada perendaman memenuhi syarat yang ditetapkan Bina Marga 2010 yaitu $\geq 90 \%$ sedangkan pada nilai IRS 2 mengalami penurunan sangat drastis yang artinya lamanya perendaman sangat berpengaruh pada nilai durabilitas campuran hasil ini sejalan dengan penelitian Ramdhan (2018).

Grafik hubungan antara nilai IDP (indeks durabilitas pertama) dengan variasi subtitusi agregat halus dapat dilihat pada Gambar 11 sebagai berikut.

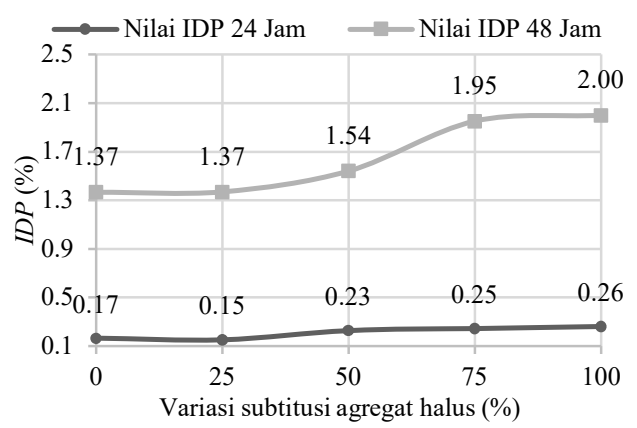

Gambar 11. Grafik pengaruh variasi subtitusi pasir pantai terhadap nilai IDP

Berdasarkan grafik dari Gambar 11 dapat dilihat nilai IDP 24 jam pada perendaman mengalami kenaikan yang mengindikasikan hilangnya kekuatan pada penambahan variasi subtitusi agregat halus, begitu juga Pada nilai IDP 48 jam terjadi kenaikan nilai IDP. Hasil ini sejalan dengan penelitian Ramdhan (2018).

Grafik hubungan antara nilai IDK dengan variasi subtitusi agregat halus dapat dilihat pada Gambar 12.

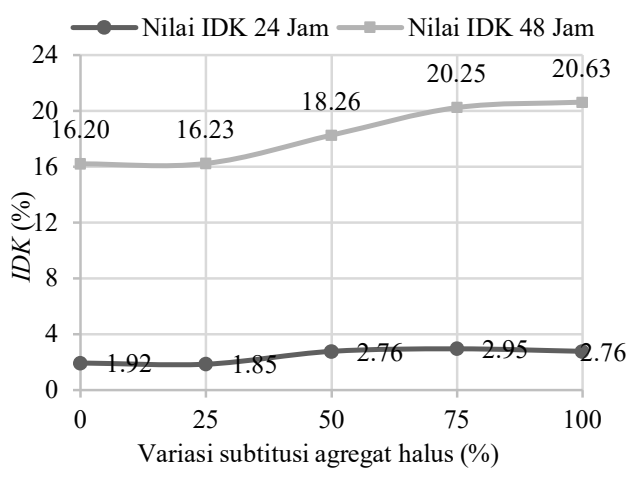

Gambar 12. Grafik pengaruh variasi subtitusi pasir pantai terhadap nilai IDK

Nilai IDK pada perendaman mengalami kenaikan yang mengindikasikan hilangnya kekuatan pada penambahan variasi subtitusi 
agregat halus. Pada nilai IDK 48 jam terjadi kenaikam nilai IDK hasil ini sejalan dengan penelitian yang dilakukan oleh Ramdhan (2018).

\section{KESIMPULAN}

Berdasarkan pengujian yang telah dilakukan, diperoleh beberapa kesimpulan sebagai berikut ini.

1. Sifat fisik pasir pantai Indrayanti memenuhi persyaratan yang telah ditetapkan oleh Bina Marga 2010, sehingga dapat digunakan sebagai bahan pengganti dalam campuran aspal

2. Parameter Marshall properties pada kinerja volumetrik dan stabilitas menurun setiap penambahan kadar substitusi pasir pantai Indrayanti, namun masih memenuhi spesifikasi Split Mastic Asphalt yang ditetapkan Departemen Perkembangan Wilayah (1999).

3. Nilai kuat tarik tak langsung pada uji Indirect Tensile Strength (ITS) menurun seiring penambahan kadar substitusi pasir pantai Indrayanti yang dipengaruhi oleh tekstur permukaan pasir pantai yang lebih halus mempengaruhi campuran menjadi mudah lepas karena tarik.

4. Ketahanan campuran pada disintegrasi pada uji Cantabro mengalami kenaikan dengan bertambahnya variasi pasir pantai yang artinya mengalami kehilangan berat akibat benturan seiring bertambahnya variasi subtitusi pasir pantai.

5. Pada uji IRS nilai durabilitas semakin rendah dengan bertambahnya kadar pasir pantai Indrayanti namun masih sesuai dengan ketentuan Bina Marga 2010.

\section{DAFTAR PUSTAKA}

Arifriardi, I., Hadi, W., \& Purnomo, A. (2016). "Pengaruh Penggunaan Pasir Pantai Carita Sebagai Campuran Agregat Halus Pada Lapis Permukaan Aspal Beton Terhadap Persyaratan Parameter Marshall”. Jurnal Menara jurusan Teknik Sipil FT.UNJ, 112-127.

Bestari, A. (2013). "Studi Penggunaan Pasir Pantai Bakau SebagaI Campuran Aspal Beton Jenis Hot Rolled Sheet (HRS)". Anterior Jurnal, 2, 13-22.

Direktorat Jenderal Bina Marga. (2010). "Spesifikasi umum 2010 divisi 6". Direktorat Jenderal Bina Marga. Jakarta.

Kusharto, H. (2004). "Pengaruh Penggunaan Pasir Pantai Terhadap Sifat Marshall Dalam Campuran Beton Aspal”. Media Komunikasi Teknik Sipil, 91-99.

Pataras, M., Astira, I. F., Rankuti, P., \& Roynaldo, B. (2017) ."Analisis Penggunaan Pasir Pantai, Darat, Dan Sungai Terhadap Kinerja Laston dan Lataston Wearing Course". Prosiding simposium II UNIID, 479-487.

Priyowardono, O. Y. (2004). "Pengaruh Waktu Terhadap Daya Tahan Lapis Perkerasan yang Menggunakan Bahan Susun Pasir Pantai”. Tugas Akhir(tidak dipublikasi) Yogyakarta. Universitas Atma Jaya. Yogyakarta

Ramdhan, A. F. (2018). "Analisis Workabilitas dan Durabilitas Material Spilt Mastic Asphalt (SMA) Grading 0/11 Pada Gradasi Batas Atas, Batas Bawah, Dan Batas Tengah". Universitas Muhamadiyah Surakarta. Surakarta

Shabrina, A. (2019). “Analisis Pemanfaatan Pasir Pantai Kemala Sebaha Bahan Tambah Campuran Asphalt Concretewearing course (AC-WC) Terhadap

\footnotetext{
Ramadhan - Kinerja Campuran SMA dengan Menggunakan Pasir Pantai Indrayanti Sebagai Pengganti ... $\quad 41$
} 
Marshall Properties Dan Nilai Struktural". Universitas Muhamadiyah Surakarta. Surakarta

Standar Nasional Indonesia (2002). "Spesifikasi bahan pengisi untuk campuran beraspal SNI 03-6723-2002". Badan Standar Nasional. Jakarta.

Sunarjo, S., \& Samantha, R. (2012). "Analisis kekuatan Tarik Material Campuran SMA (Split Mastic Asphalt) Grading 0/11 Menggunakan Sistem Pengujian Indirect Tensile Strength". Seminar Nasional Teknik Sipil UMS, 5764.
Tahir, A. (2011). "Kinerja Campuran Split Mastic Asphalt (SMA) yang menggunakan serat selulosa alami dedak padi”. Jurnal Rekayasa dan Manajemen Transportasi. Volume 1, 21-41.

Zakaria, H., \& Fauziah, M. (2012). "Optimasi Penggunaan Pasir Bengawan Solo Sebagai Agregat Halus Pada Campuran Asphalt concrete bindercourse (AC-BC)". Jurnal Rekayasan Sipil, 82-92. 